\title{
Holocaust Education in the Primary School: some reflections on an emergent debate
}

\author{
GEOFFREY SHORT \\ School of Humanities \& Education, University of Hertfordshire, UK
}

\begin{abstract}
Recent years have witnessed the beginnings of a debate over whether the Holocaust should be taught in primary schools. In this article the claims advanced in favour of the proposal are shown to be plausible but lacking in empirical support, while the counter-claims are considered either peripheral, contentious or contrary to established research. It is argued that some key omissions in the debate, such as the way primary school pupils conceptualise Jewish culture and identity, significantly strengthen the case against introducing young children to the Holocaust.
\end{abstract}

\section{Introduction}

The expanding literature on Holocaust education took a controversial turn a few years ago when the American academic Harriet Sepinwall (1999) suggested how the subject could be made appropriate for primary school pupils, from the kindergarten to grade 4 . She was responding to the views of a growing number of commentators who question the subject's suitability for young children but who nonetheless believe that some of its lessons need to be taught at this level. Sepinwall herself argued, among other things, for the importance of teaching tolerance and respect for difference. More generally, her recommendations were based on the experiences of a group of teachers in New Jersey, a state with a Holocaust curriculum for kindergarten to grade 8 that aims to encourage positive self-esteem and an appreciation of diversity while gradually incorporating concepts relevant to the Holocaust. There has been no formal assessment of this or any similar curriculum, but anecdotal evidence indicates that children in New Jersey enhanced their critical thinking skills and displayed more considerate behaviour towards others. In supporting an early introduction to the Holocaust, it should not be thought that Sepinwall is unaware of potential problems. For example, in respect of the teaching resources utilised by primary schools, she notes that while many books are appropriate for the lower grades, some contain material that 'might frighten young children' (p. 6). Research by fellow American educator, Karen Shawn (1999, p. 423), has reinforced this concern, for she not only observed 'a discernible (and disturbing) trend toward publishing Holocaust literature for ever-younger primary grade students' but claimed that 'many of these works are more graphic and depressing than those aimed at middle and high school students.' She advised that 'no book about the Holocaust, even the simplest, be made available below second grade' (p. 424), but was quite prepared to recommend reading material thereafter. 
Advocates of primary schoool-based Holocaust education in the United Kingdom have tended to focus on a slightly older age range than that which interested Sepinwall. They have also placed more emphasis on the subject as a historical event and less on its role as a source of moral guidance. Prominent campaigners Henry Maitles and Paula Cowan (1999) maintain that primary school teachers are more likely than their secondary counterparts to adopt a cross-curricular, multi-disciplinary approach to the subject and are better positioned to respond to pupils' concerns with flexibility and immediacy. The Scottish teachers they interviewed centred their approach to the Holocaust around the life of Anne Frank and, to varying degrees, made use of the teaching pack Into Hiding (Rendell, 1987). Contrary to the strictures of Lucy Dawidowicz (1992), they apparently employed role-play to good effect and claimed, in addition, that their 9- to 11-year-old pupils benefited from watching videos and from listening to Holocaust survivors. The only criticism they had of the teaching pack was that it provided no description, detail or definition of the extermination camps. They found their own ways of dealing with this key omission and seem to have done so without difficulty, prompting Maitles and Cowan to conclude that the Holocaust is not 'too harrowing a study for primary pupils' (p. 270). This inference is consistent with research carried out over recent decades showing that young children are able to cope intellectually and emotionally with political topics previously thought suitable only for an older age group (Carrington \& Troyna, 1988). Of course, the practical advantages that the primary school enjoys vis à vis the secondary are of no consequence unless it can be shown that young children are likely to profit in some way from learning about the Holocaust. To this end, Maitles and Cowan draw attention to the existence of racism among primary school pupils and crucially to the advantages of an early intervention in order to combat it. They maintain that the Holocaust can play a helpful role in the process for it deals with a host of issues relevant to citizenship and values education. In their view, it has the potential not only to enhance pupils' understanding of 'racism, stereotyping and discrimination' but also to broaden their awareness of 'justice, tolerance, (equality of) treatment and the dangers of fascism' (p. 264). Given the nature of these benefits and the tendency for teachers in Maitles and Cowan's study to link the Holocaust with Judaism, it is no surprise that the researchers found the topic often taught as part of the Religious and Moral Education curriculum. Certainly, Broadbent's (1999) analysis of the aims of Religious Education demonstrates its compatibility with learning about the Holocaust. She notes, for example, that the subject seeks to 'develop pupils' abilities to make reasoned and informed judgements about religious and moral issues and to foster ... a positive attitude towards others' (p. 73).

Support for primary schools teaching about the mass murder of European Jewry (and other victims of genocide) has also come from the British government. In a publication it produced for the first annual Holocaust Memorial Day (Department for Education and Employment, 2000) suggestions were made for two Year 6 assemblies, one dealing with issues relating to difference, the other with the traumatic experiences of the Kindertransport children. In recommending as a follow-up activity that pupils discover what they can about atrocities committed against the Jews, the government added its voice to those who believe that it is possible to teach a reasonably unsanitised account of the Holocaust in the final year of primary school. Such a claim is, in fact, a relatively modest one, for some individuals and organisations maintain that the subject can be introduced at an even younger age, though few have gone as far as The Anne Frank Educational Trust (1996) in proposing an assembly on the life of Anne Frank for 5-year-olds. This contentious suggestion is discussed below, in the context of a more general appraisal of Holocaust education in the primary school. 


\section{Misdirected Criticisms}

The strongest condemnation of teaching the Holocaust in the early years has come from the American writer Sam Totten (1999). In a rejoinder to Sepinwall, he objects to her use of the term 'Holocaust education' to describe moral lessons drawn from the Nazi genocide and argues that classroom discussion of universal themes such as tolerance are more properly classified under the rubric of prejudice reduction or human rights awareness. In his view, Holocaust education is a misnomer when used to refer to anything other than the genocide itself and the events leading up to it. More controversially, he contends that those events cannot be taught to children below the age of 9 or 10 unless they are so watered-down or otherwise distorted as to verge on travesty. In contrast to the literature on primary pupils' political sophistication alluded to in the introduction, Totten believes that young children will struggle with the history because of its complexities and fears that they will suffer emotionally if exposed to its horrors.

I find Totten's critique unconvincing on a number of grounds. It is marred by a misplaced emphasis on terminology and by a lack of evidence to support claims made about the preadolescent's intellectual and emotional immaturity. It also ignores both relevant research findings and some important theoretical questions that arise from too early an acquaintance with the Holocaust. In my view the priority is not to challenge the legitimacy of the term 'Holocaust education' to describe lessons derived from the genocide; it is rather to question whether the derivations themselves are legitimate. In this respect Sepinwall's assertions about the need to teach tolerance and respect for difference are problematic, for neither follows from a study of the Holocaust. Indeed, it can be argued that the chain of events culminating in the attempted annihilation of European Jewry reflects a degree of tolerance that was morally reprehensible. One might cite, as examples, the willingness of the Weimar Republic to grant free speech to racists and the failure of the Vatican to speak out publicly against the iniquities inflicted on the Jews (e.g., Cornwell, 1999). In itself, tolerance is not a virtue and children should not be encouraged to think that it is. An unrestrained relativism in which anything goes can only serve the interests of political extremism, an outcome patently at odds with the aims of Holocaust education.

Lessons relating to respect for difference again reveal a fundamental misunderstanding of the Holocaust for they assume that the Jews were discriminated against and ultimately murdered simply because they deviated from societal norms. If that were the case, one has to ask why others who were in some sense 'different' such as the red-haired, the seriously overweight and the sporting elite did not have to endure the same fate. The reality, of course, is that the Jews were singled out because they were held responsible for Germany losing the war; they were seen as exercising a malign influence over the economy and were suspected of harbouring communist sympathies. That said, their persecution cannot be explained adequately without also taking account of the less immediate but nonetheless potent influence of the long tradition in Germany (and elsewhere in Europe) of Christian antiSemitism. The educational implications of this analysis plainly have nothing to do with an appreciation of difference but point instead to understanding the nature and dangers of stereotyping and its connection with the scapegoating process. (Short and Carrington (1991) suggest that the former, at least, can be taught successfully to primary-aged pupils.) The analysis also highlights the need to ensure that children are familiar with those changes in Protestant and Catholic theology that have occurred over recent decades insofar as they affect Jews. I refer principally to the historic charge of deicide.

Totten's critique of primary school involvement with the Holocaust is unpersuasive not just because its focus is misdirected, but because its claims are unsupported. He provides no evidence, direct or circumstantial, to back his assertion that for the subject to retain its 
academic integrity its conceptual demands must necessarily exceed the intellectual reach of most young children. It is certainly not self-evident that the narrative needs to be 'simplified beyond recognition' in order to be understood by grade 4 pupils. The success of Daniel's Story, an exhibit at the United States Holocaust Memorial Museum, testifies to the contrary. Totten writes as though unaware of the extensive literature that has accumulated over the past thirty years or so challenging basic Piagetian beliefs about young children's cognitive limitations (e.g., Donaldson, 1978; Wood, 1998). The truth is that in the absence of relevant research we can only guess at how children of primary school age will respond if presented with an elementary yet fundamentally honest account of the Holocaust. Although a recent investigation in England found considerable ignorance and confusion among adolescents who had studied the Holocaust the previous year (Short, 2000a), it would be unwise to extrapolate from that research to the situation in primary schools. The findings might simply reflect the restricted opportunities for effective Holocaust education within Key Stage 3 of the National Curriculum (designed for 11- to 14-year-olds). Other research conducted in secondary schools has noted the emotional impact on some pupils of learning about the Holocaust (e.g., Short, 1995), but it would be rash to assume that the impact would necessarily be more traumatic with younger pupils. Once again, Totten provides no data to justify his apprehension.

It is ironic that among the issues supportive of Totten's position but omitted from his critique is one that has attracted the interest of researchers. It concerns children's understanding of Jewish culture and identity, a matter of obvious relevance to the debate on Holocaust education in the primary school.

\section{Young Children's Understanding of Jewish Culture and Identity}

According to social psychologist Melvin Lerner (1977) it is human nature to believe in a just world. Consequently, we tend to interpret suffering, regardless of any appearance to the contrary, as a manifestation of deserved punishment rather than as an ostensible injustice. Consistent with this claim, Piaget (1932) coined the term 'immanent justice' to describe the young child's inclination to construe misfortune following upon the commission of a misdeed not as coincidence but as a form of retribution. Clearly, if Lerner's hypothesis is well founded, children will not necessarily recoil in horror when they learn about the Holocaust. Indeed, should they believe, for whatever reason, that Jews are in some sense 'bad people', they will be even more strongly minded to think in terms of blaming the victim (Ryan, 1971). Their reaction to discovering that millions of Jews were systematically slaughtered may be less one of revulsion than of joy at the perceived triumph of good over evil. In light of this possibility, Holocaust education must prioritise the need to expose and challenge pupils' misconceptions of Jews. However, the debate over whether to teach the Holocaust at primary level has signally failed to take account of research into how children perceive Jewish culture and identity. I turn now to consider this body of work and reflect on its relevance for curriculum development.

The research (Short, 1991; Short and Carrington, 1995) involved interviews with two groups of primary school pupils, one aged between 8 and 10, the other between 10 and 12 . Altogether there were 81 boys and 57 girls. Those in the younger age group attended a socially mixed, non-denominational school in an area of south-east England adjacent to a substantial Jewish community. The older children were drawn from four schools; one in the north-east of England and three in the south-east. The northern school had a working-class catchment and was located within a few miles of both a mainstream Jewish community and a Chassidic (ultra-orthodox) one. The southern schools were predominantly middle-class and rather closer to mainstream Jewish communities. There is no suggestion that the 
children were representative of their respective age groups for one would expect responses to the interviews to vary as a function of many factors including geographical location, ethnic composition of the school and religious affiliation of the pupils. Virtually all the children were white and nominally Christian. Nonetheless, they may be considered sufficiently representative to suggest some of the limitations, as well as the possibilities, of teaching the Holocaust in the primary school.

\section{8- and 9-Year-Olds}

At an early stage in the interview, the children were asked if they had ever heard the words 'Jew' or 'Jewish'. Among those answering in the affirmative, some clearly had little or no idea what either word referred to.

Claire: (8 years, 6 months) I think so, once. I heard someone say it.

Michael: (8:7) Yes. Is it a language?

Pamela: $\quad(9: 1)$ Yes. In a book I think. Was Jews a name?

Paul: $\quad(8: 6)$ I heard it in Assembly once.

Interviewer: Can you remember what was said?

Paul: $\quad$ No.

Among those who did possess a rudimentary concept of a Jew, there was still a fair amount of confusion. A number of children, for instance, saw Jews as necessarily alien and the notion of a British Jew seemed incomprehensible to some of them.

Interviewer: Have you ever heard the word 'Jewish'?

Peter: $\quad$ Yes.

Interviewer: What have you heard?

Peter: $\quad$ People from Jerusalem. They're Jewish.

Interviewer: So, if you are born in England, can you be Jewish?

Peter: $\quad$ Yes, if you go to Jerusalem for a long time.

Thinking along similar lines, Matthew (9:2) maintained that we do have Jewish people in England because 'they could come here for a holiday.' Asked if it was possible for someone Jewish to be born in England, he said it was not. Alex (8:7) also perceived Jews as foreign but it is not clear whether this was because he had only ever encountered the ultra-orthodox (with their distinctive appearance) or because he confused Jews with Sikhs.

Interviewer: If you could choose to be Christian or Jewish, which would you prefer or are you not bothered?

Alex: Christian, because Jewish people are sort of foreign-all funny ways.

Interviewer: So you think Jewish people in this country are foreign, do you?

Alex: $\quad$ Yes.

Interviewer: Why do you think that?

Alex: $\quad$ Because when you look at them they got sort of a funny beard and they got something round their head and (it) just doesn't look like a British person.

These boys' remarks are particularly noteworthy in the light of Grugeon and Woods' (1990) observations on a project on Judaism carried out in England by a group of 7-and 
8-year-olds. After talking to the children, the researchers concluded that 'there was a general feeling that Jews were not English.'

In summary it would appear that many 8-and 9-year-olds either possess no concept of a Jew, or subscribe to one that is quite inaccurate. Much preparatory work on the nature of Jewish identity will therefore be required before children of this age are able to acquire even a superficial understanding of the Holocaust. At a minimum, they will need to grasp the notion of Jewishness as a racial category that was central to Nazi ideology (while at the same time, of course, learning to repudiate it). Whether such understanding is feasible in the lower primary school is unknown but there is evidence that slightly older children can be helped to recognise both racial and religious definitions of a Jew. The relevant findings are discussed below.

\section{0- and 11-Year-Olds}

It was the 10- and 11-year-olds in just one of the schools in south-east England who were questioned about the nature of Jewish identity. They proved to be aware of the distinction between racial and cultural characterisations of Jewishness partly, perhaps, because they had been taught the previous year by a woman who was the daughter of a Jewish mother (who had fled Nazi Germany) and a non-Jewish father. The teacher had spoken at length to the class about her mother's pre-war experiences and of her own lack of commitment to Judaism.

Having explored with the children their knowledge of different religions and of Judaism in particular, they were asked what they knew about Jewish people. The comments of Tanita and John (interviewed together) are typical and leave no doubt that some children of this age, and perhaps the majority, are able to understand Jewishness as a racial as well as a religious designation.

Tanita: $\quad$ Our last teacher used to tell us something because she was halfJewish. She was Jewish by 'race' not religion.

Interviewer: What does that mean?

Tanita: She was born Jewish but she didn't take it into her religion. She didn't go to the religious things.

Interviewer: If someone is born Jewish and wants to become a Christian, will they stop being Jewish?

Tanita: No, I don't think so. They will always be Jewish but they can act like a Christian.

John: $\quad(11: 0)$ You're still partly Jewish.

Interviewer: What do you mean?

John: $\quad$ Your parents are. You're Jewish by blood, but you make yourself think that you're not.

Interviewer: If, when you are born, your parents are Christian, can you later become Jewish?

John: $\quad$ Yes, but you would still, in your blood, be a Christian.

It was earlier implied that if Holocaust education is to be undertaken successfully with children of any age we need to know more about their thinking than whether they are able to categorise Jews from both a racial and a religious point of view. We also need to know how they perceive Jews and Judaism and, in a predominantly 'Christian' society, how they perceive the relationship between Judaism and Christianity. To tap their familiarity with antiSemitic stereotypes the children were asked if they had ever heard anything unkind said 
about Jews. [In order to avoid any suggestion of an anti-Semitic bias, they had previously been presented with a similar question about Christians.] It transpired that many of them were cognisant of an unsavoury association of Jews with money.

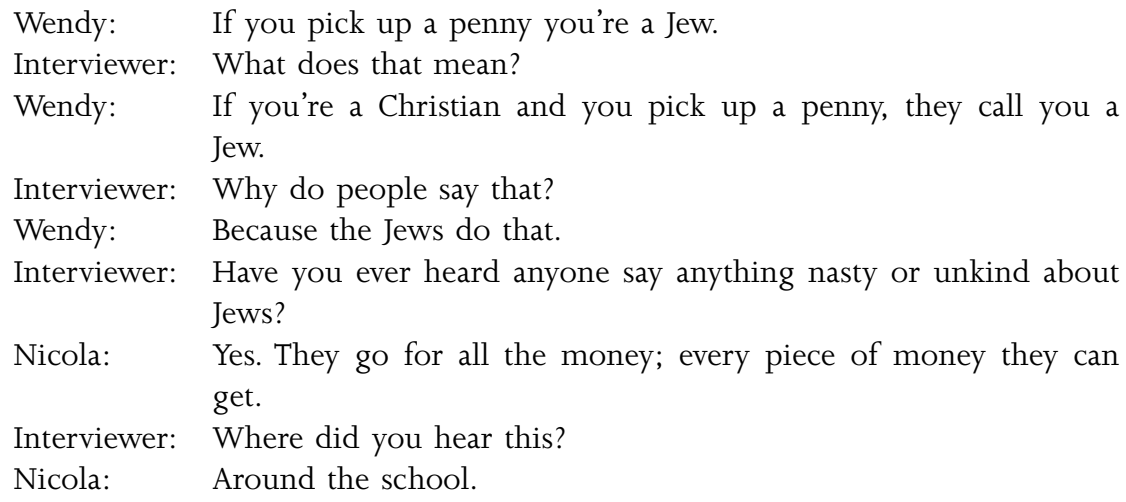

It is not just familiarity with anti-Jewish stereotypes that might inhibit an appropriate response to the Holocaust, for misconceptions of Judaism could easily have the same effect. By way of illustration, some of the 10- to 11-year-olds, when asked to say what they knew about the Jewish religion, articulated notions that were not just outlandish, but involved the sort of ignorance that may well invite contempt for Jews. For example:

They have Passover. It's when angels come over killing every baby boy and you have to put blood on your door so that they don't come.

When they die, my dad said, they keep their jewellery in their grave.

One of the more common misconceptions was that Jews and Christians worship different gods. Some children thought that Jews worshipped quite a few.

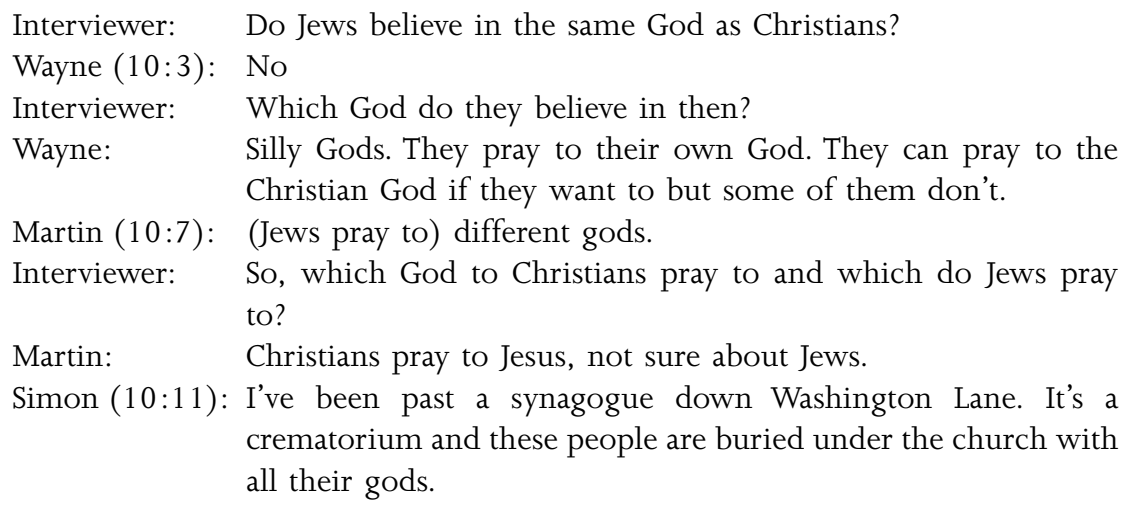

It also emerged that considerably more than half the sample did not know that Jesus was a Jew and $14 \%$ were prepared to blame the Jews, without qualification, for his death. Plainly, such 'knowledge' is not helpful to children from Christian or nominally Christian homes conceptualising Nazism as an unmitigated evil. The latter demands that much curricular time be given over to revealing children's ignorance and exposing their misconceptions not just of Jews, but of Judaism as well and particularly its relationship with Christianity. 


\section{Resources for Teaching the Holocaust to Young Children}

In the debate over Holocaust education in the early years, much of the discussion of teaching resources has focused on their likely impact on pupils' emotions. This one-sided analysis is regrettable for it distracts attention from other ways in which the resources might be unsuitable. For example, the most popular curricular guidance in the United Kingdom, at present, is arguably to be found in the teaching pack produced by the Anne Frank Educational Trust (1996), a publication which has been purchased by thousands of schools. Most of its suggested activities are aimed at teachers of 7- to 11-year-olds and have the twin purpose of providing information about the life of Anne Frank and assisting children to become more tolerant and also more appreciative of living in a democratic society. I propose to comment on the one activity recommended for 5- to 7-year-olds that was referred to in the introduction. It is suggested that schools hold an assembly for children in this age group with the aim of making them aware of 'Anne Frank as someone who was special and (of exploring) and celebrat(ing) friendship as a special relationship.' A story is to be read to the children which starts as follows:

There once lived a girl called Anne Frank. She was born in the city of Frankfurt in Germany on 12 June 1929. In that country there were people who hated Jews. They were called Nazis. Four years after Anne Frank was born, the Nazis and their leader Adolf Hitler became the most powerful people in the land. Anne Frank and her family were Jews and so they knew that soon their lives would be in danger. They moved to another country called Holland where they could feel safer.

In view of the evidence showing that 8 - and 9-year-olds have almost no conception of a Jew, one wonders what 5- and 6-year-olds will make of this story. One wonders too how a teacher would respond if a child, quite reasonably, were to ask, 'What is a Jew and why did the Nazis not like them?' To discuss with young children the nature and value of friendship (and to include in the discussion references to inanimate 'friends' such as diaries) is entirely proper, but to do so in relation to Anne Frank would seem to complicate the issue unnecessarily. Moreover, it is far from clear just what purpose is served by making children aware of Anne Frank at so young an age.

It will be recalled that one of the grounds on which Totten objects to Holocaust education in the lower primary school is that young children are intellectually incapable of handling the historical context in which the tragedy unfolded. He points out that the resultant need to simplify the history necessarily distorts it and thus diminishes its value. While claiming, controversially, that the simplification inevitably violates historical truth, there is clearly a risk that in attempting to render the material comprehensible, authors will resort to the use of stereotypes. This danger is evident in The Number on My Grandfather's Arm (Adler, 1987), one of the books recommended by Karen Shawn (1995) for children in grades 2 to 4 . The narrator is a seven-year-old girl who asks her grandfather to explain the tattoo he reveals one evening when rolling up his sleeve to wash the dishes. Recounting his life story, he says to the girl at one point, 'There were a great many problems in Germany. Hitler blamed them all on the Jews. Of course that was nonsense. But the German people were happy to blame someone' (Adler, op. cit. 14, Emphasis added). This tendency to treat the Germans as a monolithic entity is exacerbated by the author subsequently using the words 'Germans' and 'Nazis' interchangeably. On a related note, the book can also be accused of encouraging readers to see all non-Jews as anti-Semitic, for after describing the various forms of abuse experienced by the Jews in Germany, the grandfather remarks, 'In other countries, too, in Italy, Hungary, Austria, Yugoslavia, and in my Poland, people all talked about how they hated the Jews' (ibid., p. 14). 
One of the consequences of an overriding concern with the emotional dimension of Holocaust literature is that books that are not especially upsetting may be considered suitable for young readers even though they offer little or no enlightenment on the fate of the Jews during the Nazi era. The Lily Cupboard (Oppenheim, 1992), a fictional tale recommended by Shawn for children in grades 2 to 4 , is a case in point. It tells the story of a young Jewish girl forced to leave her parents' home and hide with strangers during the German occupation of Holland. When enemy soldiers approach, she has to secrete herself away in a cupboard. The reader is told in the opening paragraph that during the occupation 'Jews, in particular, were sent to concentration camps where many died a hideous death', but this is one of just three references that the text makes to Jews. The second occurs when the girl's parents tell her that she will be safer staying with the family 'because (they are) not Jewish', while the third appears at the end of the book when the author writes that, 'families like this one hid Jewish children for five years till the war ended and saved many lives at the risk of their own.' The storyline, such as it is, revolves around the relationship between the girl and her pet rabbit, but from the standpoint of learning about the Holocaust the main problem with the book is that the critical background events are completely de-contextualised. The reader is given no insight into why Jews were more vulnerable than other sections of the population following the German invasion and why Dutch families who sheltered them often paid for such selflessness with their lives. It is thus difficult to understand why Shawn should choose to commend the book as 'a fine introduction to the Holocaust for students completely unfamiliar with the subject’ (op. cit., p. G5).

\section{Why Not Wait Until Secondary School?}

There can be no objection to young children learning lessons that are legitimately derived from the Holocaust. Indeed, it has been argued that pedagogic strategies aimed at reducing prejudices of various kinds are more likely to succeed at primary than at secondary level where peer group pressure might exert a powerful countervailing force (Short \& Carrington, 1995). The justification for teaching primary aged pupils about the Holocaust itself, however, is much less convincing largely because of a dearth of supporting empirical research. The assumption that young children are able to cope intellectually with the complexities of the subject underlies Maitles and Cowan's endorsement of primary school engagement with the Holocaust but, like Totten, they offer no evidence to back their claim, basing their conclusions entirely on the views of teachers.

But even if research (focused on pupils rather than their teachers) were to establish the viability of Holocaust education in the primary school it would not necessarily follow that it should be undertaken at that stage. In countries such as Scotland where the Holocaust is not a mandatory component of the secondary curriculum, the case for its inclusion during the primary years is obviously strengthened, for the alternative would be to risk students leaving school with little or no knowledge of one of the watershed events of the twentieth century. But where the Holocaust is compulsory in secondary schools, as it is in England and Wales, teaching it to younger children could prove damaging in ways that proponents and detractors alike have failed to recognise. For example, it could easily contribute to 'Holocaust fatigue'. Students may tire of the subject if, having learnt about it at primary school, they encounter it again at secondary school, not just in the History syllabus but also, perhaps, in English and in Religious Education. That this speculation is soundly based emerged in the course of a recent survey that investigated Holocaust education in Canadian high schools (Short, 2000b). When asked whether there were any drawbacks to teaching the subject, the head of the history department in one school said: 
I suppose it can be over-done. You get kids who, when you say 'we're going to do . . .' say, 'Oh, not again' because they've got it in English (and) they may have done it before. They may feel they are being manipulated, that somehow or other this particular event is being taught to death in the case of some kids.

There is actually a more serious problem than fatigue that might result from over-exposure to the Holocaust and it was alluded to in the comment just cited. It concerns the feeling of manipulation that might well breed a degree of antipathy which, in turn, could render Holocaust education not just ineffective but counter-productive. The psychological notion of 'reactance' (Brehm, 1966) helps to explain how such an eventuality might come about for its basic premise is that individuals possess a fundamental need to see themselves as having the power to make their own decisions. Any perceived attempt to restrict this sense of freedom (such as pressure to acknowledge the importance of the Holocaust and learn its lessons) will be resented and, in all probability, rejected in order that the individuals concerned may regain a sense of control over their own destiny.

Those who support primary schools teaching about the Holocaust will have to engage with the issues of fatigue and reactance and will also have to recognise the substantial preparatory work needed to apprise young children of the nature of Jewish culture and identity and the Jewish roots of Christianity. Taken together, these factors weigh heavily against an early introduction to the Holocaust, but in the final analysis, their influence depends on the strength of the counter-arguments put by those who favour the proposal. In this respect, the case made by Sepinwall is a weak one, for she offers no such counterargument; in fact, she does no more than affirm the importance of moral guidance derived from the Holocaust. Maitles and Cowan, in contrast, explicitly defend teaching the historical narrative, but their arguments, though plausible, are not compelling. While they maintain, reasonably enough, that racism should be tackled at the earliest opportunity and contend that the Holocaust can play a useful part in the process, they provide no evidence that it does so. Without this evidence it is difficult to know how, if at all, children would suffer if they were to remain ignorant of the Holocaust until adolescence. Maitles and Cowan also stress the importance of a cross-curricular approach to the subject, but on this point they admit only that primary schools are more likely than their secondary counterparts to adopt such an approach. They claim too that secondary school students are disadvantaged by their teachers' inability to respond with the same flexibility and immediacy that is available to teachers in primary schools, but once again, they fail to substantiate the claim. It is this lack of empirical support, together with the problems of fatigue and reactance, that undermines the case for young children learning in school about the Holocaust, although of course it has no bearing on the demand that they should learn from it.

Correrspondence: Geoffrey Short, School of Humanities \& Education, University of Hertfordshire AL10 9AB, UK.

\section{References}

Adler, D.A. (1987) The Number on My Grandfather's Arm, New York, UAHC Press. Anne Frank Educational Trust (1996) Anne Frank, London, Anne Frank Educational Trust. Brehm, J.W.A. (1966) A Theory of Psychological Reactance, New York, Academic Press.

BROADBENT, L. (1999) Religious Education: a challenge for religion and for education. In: J.E Riley \& R. Prentice (eds) The Curriculum for 7-11 Year Olds, London, Paul Chapman Publishing. 
Carrington, B. \& Troyna, B. (eds) (1988) Children and Controversial Issues, London, Falmer Press.

Connwell, J. (1999) Hitler's Pope: The Secret History of Pius XII, Harmondsworth, Viking.

Dawidowicz, L. (1992) What's the Use of Jewish History? New York, Schocken Books.

Department for Education \& Employment (DfEE) (2000) Remembering Genocides: lessons for the future, London, Department for Education and Employment.

Donaldson, M. (1978) Children's Minds, Glasgow, Fontana/Collins.

Grugeon, E. \& Woods, P. (1990) Educating All: multicultural perspectives in the primary school, London, Routledge.

Lerner, M.J. (1977) The Justice Motive: some hypotheses as to its origins and forms, Journal of Personality, 45, 1-52.

Maitles, H. \& Cowan, P. (1999) Teaching the Holocaust in primary schools in Scotland: modes, methodology and content, Educational Review, 51, 3, 263-272.

Oppenheim, S.L. (1992) The Lily Cupboard: a story of the Holocaust, New York, Harper-Collins.

Piaget, J. (1932) The Moral Judgement of the Child London, Routledge and Kegan Paul.

Rendell, F. (1987) Into Hiding: a topic study on Anne Frank, Glasgow, University of Strathclyde.

Ryan, W. (1971) Blaming the Victim, New York, Pantheon.

Sepinwall, H. (1999) Incorporating Holocaust education into K-4 curriculum and teaching in the United States, Social Studies and the Young Learner 10, 5-8.

SHawn, K. (1995) What should they read and when should they read it? A selective review of Holocaust literature for students in grades two through twelve, Part 1, Dimensions; $A$ Journal of Holocaust Studies, 8, 5, (Section G).

SHawn, K. (1999) What should they read, and when should they read it? A selective review of Holocaust literature for students in grades 2 through 6. In: J. P. ROBERTSOn (Ed.) Teaching for a Tolerant World, Urbana, IL: National Council of Teachers of English.

SHORT, G. (1991) Teaching the Holocaust: some reflections on a problematic area, British Journal of Religious Education, 14, 1, 28-34.

SHorT, G. (1995) The Holocaust in the National Curriculum: a survey of teachers' attitudes and practices, Journal of Holocaust Education, 4, 167-188.

Short, G. (2000a) Holocaust Education and Citizenship: a view from the United Kingdom. In: M. Leicester, C. Modgil \& S. Modgil (eds) Education, Culture and Values, London, Falmer Press.

SHORT, G. (2000b) Holocaust education in Ontario high schools: an antidote to racism? Cambridge Journal of Education, 30, 2, 291-306.

Short, G. \& Carrington, B., (1991) Unfair discrimination: teaching the principles to children of primary school age, Journal of Moral Education, 20, 2, 157-177.

Short, G. \& Carrington, B. (1995) Anti-Semitism and the primary school: children's perceptions of Jewish culture and identity, Research in Education, 54, 14-24.

Totтen, S. (1999) Should there be Holocaust education for K-4 students? The answer is no, Social Studies and the Young Learner, 12, 36-39.

Wood, D. (1998) How Children Learn and Think, Oxford, Blackwell. 